\title{
The Application of Jigsaw Cooperative Learning Model towards the Improvement of Students' Critical Thinking Ability in Public Senior High School 15 Banda Aceh, Indonesia
}

\author{
Ismail \\ Faculty of Social and Political Sciences, Universitas Iskandar Muda, Aceh, Indonesia \\ ismail.unida@gmail.com
}

\section{Abstract}

The purpose of this study is to analyze the application of Jigsaw Cooperative Learning model towards the improvement of students' critical thinking ability in Public Senior High School 15 Banda Aceh, Indonesia. The results showed that the students' ability in answering questions before learning using the jigsaw learning model was still in the low category or the initial research proved that most students were not able to answer the questions well, so the researchers took the next action, namely learning by using a jigsaw type cooperative learning model, the results of information obtained from learning conducted before the implementation of the study, while the information from the control class is low category consisting of 3 students, while the medium category is 9 students, and while the high category there are 7 students while the information in the experimental class is low category consists of 1 student, 11 students and a high category of 8 students, which can be concluded that there are differences in students' critical thinking outcomes with the use of a jigsaw type cooperative learning model.
Keywords

Jigsaw Cooperative

Type; Public Senior High

School 15 Banda Aceh;

critical Thinking

\section{Introduction}

Learning is receiving knowledge, while teaching giving knowledge. In the opinion (Hanafy, 2014) "The process of behavior change can occur in a variety of conditions based on explanations from education and psychology experts while learning is an activity that progresses through stages and is systematic and requires good design, accurate implementation, and evaluation". Learning is an attempt by someone to facilitate the occurrence of a learning process for students. Learning can be interpreted as a process of interaction between students and teachers as educators and sources of learning in the learning environment.

Teachers are essentially educational staff who bear heavy human responsibilities, especially with regard to the educational process of teaching (Suprihatin, 2015) while Learning is a system created by a teacher, While learning is the process of interaction with all situations that exist around individuals (Hamiyah and Jauhar, 2014). Teaching and learning activities must be carried out by two actors, namely teachers and students. The relationship between teacher and student must be dynamic and necessary with the meaning of education (Sutrisno \& Siswanto, 2016).

Learning can be interpreted as a process of interaction between students and educators can take advantage of existing learning resources in the learning environment. In his opinion 
(Nasution, 2019) said that: learning is the effort of a teacher in shaping the desired character and behavior by providing a good learning environment or stimulus of the desired results.

The essence of learning and learning at Public Senior High School 15 Banda Acehmeans learning about oneself and the environment around them. Many problems in daily life can be solved by using learning in Public Senior High School 15 Banda Aceh. But the learning process at Public Senior High School 15 Banda Acehtends to only memorize, so this becomes an obstacle for students in understanding the subject matter.

Based on the results of researchers' observations on the subject matter contains many concepts and performance processes that must be understood, so to understand them is needed scientific work skills. One of the concepts that must be understood is the concept of Public Senior High School 15 Banda Aceh. If students only memorize these concepts in learning, student learning will not be meaningful and students will feel bored so that the subjects of Public Senior High School 15 Banda Aceh are no longer interesting. For that we need a change in the learning system that must be interesting and innovative (Ismail, 2020).

Based on the results of interviews with several teachers in Public Senior High School 15 Banda Aceh, it was explained that the learning outcomes of students who were taught by learning at Public Senior High School 15 Banda Acehall this time had an average grade of final semester exams relatively low. This can be seen from the average semester exam scores in the last three years, namely: (1) 2017/2018 school year $=65.20$; (2) 2018/2019 school year =66.79; and (3) 2013/2014 school year $=66.87$ (Source: Data of Public Senior High School 15 Banda Aceh, 2018). The high school 15 Banda Aceh learning that has been taking place is seen as a professional obligation that must be difficult to realize, including the ability of students to think critically.

\section{Review of Literature}

\subsection{Thinking Techniques}

Critical thinking is seen at any time in the process of learning and assessment, problem solving in general can be solved. Someone will try to find out what is being done and the problem that needs to be sought. The solution can be done with effort and reflection such as reading, writing, speaking and listening. All processes can be carried out critically. Critical thinking is so important to increase the potential of thinking optimally so that it becomes a careful reader and creative writer (Shamim, 2017).

To improve students 'critical thinking skills, the teacher must use learning methods and models that emphasize the activeness and creativity of students in the teaching and learning process, because they can improve students' critical thinking skills through analysis and other abilities. Such as a jigsaw cooperative model (Shaffer \& Shaffer, 2020). This is expected to bring a more interesting atmosphere and can impress students, so the learning process can be felt more fun and not make students bored. The Teaching and Learning Process is created directly to develop students' learning about knowledge about something being taught step by step. Critical thinking has a variety of methods, including; think acoustically, think realistically, think creatively and think evaluatively.

a. Think Austik 


\section{a. Think Austik}

When students fantasize and often fantasize thinking about something new sometimes not all according to the student's circumstances. Every student has been involved in this problem, but must always be in a situation that can be controlled. Therefore, students who think acoustically are often referred to as the daydreaming process.

\section{b. Realistic thinking}

Realistic thinking can be done by someone when adjusting to a real environment. In realistic thinking, a person can see the real situation that exists in his environment, then immediately give a conclusion based on what is seen, then it can be realized on a real experience. This is called realistic thinking. for example, when conditions wake up late when they want to go to school in the morning, then a student will think of alternative ways to avoid waking up late again.

\section{c. Creative thinking}

Creative thinking is also done in discovering something new. Creative thinking requires stimulus or stimulation from the environment that will be able to trigger the creativity of a student. Someone can be said to think creatively if there is a change that creates something new change. Creative thinking can also be done by utilizing definite goals, as well as completing a problem well, and can generate new ideas so that they can refine old ideas into new forms.

\subsection{Critical Thinking Definition}

Critical thinking is a process carried out by a person or individual to interpret and evaluate new information to make an assessment criteria and decisions based on the abilities that exist in him, and can apply the knowledge and experience possessed by someone. (Kowiyah, 2012).

Critical thinking is a process of thinking regularly and systematically and is most important for a person to achieve professionally. Critical thinking can help a person become professional in meeting the needs of himself and others. Critical thinking is to think by having a goal and aiming at goals that help a person make judgments based on accurate data and not based on mere estimates (mujib, 2016). Meanwhile according to (Rachmadtullah, 2015) Critical thinking based on methods can be based on scientific inquiry, which is also a root in the learning process. Critical thinking and the learning process are crucial for professional learning because this way of thinking is based on approaches, models and methods of problem solving. According to opinion (Aziz, 2015) Critical thinking is a very complex process of development based on rationalist and careful thought in terms of actual data. Being a critical thinker is a very common denominator for science that guides the disciplined or independent thinking. Knowledge is gained, tested and measured through thinking. 
Table 1. Syntax of the Cooperative Learning Model

\begin{tabular}{|c|c|}
\hline PHASE & TEACHER BEHAVIOR \\
\hline $\begin{array}{l}\text { Phase 1: present goals and sets } \\
\text { Teachers convey the objectives to } \\
\text { be achieved and prepare students }\end{array}$ & $\begin{array}{l}\text { Explain the purpose of a learning goal } \\
\text { and prepare students to be ready to } \\
\text { learn. }\end{array}$ \\
\hline $\begin{array}{l}\text { Phase 2: present information } \\
\text { Present all accurate information }\end{array}$ & $\begin{array}{l}\text { Provide information to students both } \\
\text { and verbally. }\end{array}$ \\
\hline $\begin{array}{l}\text { Phase 3: organize students into } \\
\text { learning teams } \\
\text { Organize students into learning } \\
\text { teams }\end{array}$ & $\begin{array}{l}\text { Give students an explanation of the } \\
\text { procedures for forming a learning } \\
\text { team and helping the group make an } \\
\text { efficient transition. }\end{array}$ \\
\hline $\begin{array}{l}\text { Phase 4: assist team work and study } \\
\text { Help work in teams to learn }\end{array}$ & $\begin{array}{l}\text { Help each team to learn as long as } \\
\text { students do all the work. }\end{array}$ \\
\hline $\begin{array}{l}\text { Phase 5: test on the materials } \\
\text { Evaluating team learning outcomes }\end{array}$ & $\begin{array}{l}\text { Test students' knowledge about } \\
\text { various learning materials and each } \\
\text { group can present their work. }\end{array}$ \\
\hline $\begin{array}{l}\text { Phase 6: provide recognition } \\
\text { Give appreciation and appreciation }\end{array}$ & $\begin{array}{l}\text { Prepare everything to acknowledge } \\
\text { the effort in the team and student } \\
\text { achievements both individually and in } \\
\text { groups. }\end{array}$ \\
\hline
\end{tabular}

Sources: (Havrylov, Kruszewski, \& Joulin, 2019)

\section{Jigsaw Cooperative Learning Model}

From his understanding Jigsaw comes from English which means jigsaw and there are also those who call it Fuzzle, which is a learning puzzle that makes up pieces of pictures. This jigsaw cooperative learning model also uses the pattern of how to work a saw, that is, students can do a learning process activity by making groups work together between students with one another to achieve common goals.

So learning the type of jigsaw cooperative learning model can be said as a learning model that uses a group of teams that will communicate between fellow teams when the learning process consists of four, even up to eight people in a group who have different backgrounds or can be said with heterogeneous classes. And the assessment system is carried out on groups and each group will receive an award, if the group can demonstrate the required performance. In the Jigsaw cooperative learning model, there is an origin group and an expert gr

\section{Research Method}

\subsection{Place and Time}

This research took place at Public Senior High School 15 Banda Aceh. This research was conducted in 2020. The population and sample in this study were determined by the Purposive Sampling method by giving pretest and posttest questions to all consisting of 4 classes at Adidarma High School. Before all samples in this study are determined, assumptions will be tested first as a requirement for applying a research sample, that is, the homogeneity test of variance between groups of one with the other groups, data analysis assisted by SPSS and with a significant $95 \%$. The results of data processing obtained as stated 
in the attachment. It can be seen that the sample class is normal and homogeneous terms. Based on this the sample of Class X1

\subsection{Data Collection Technique}

The critical thinking ability test uses multiple choice which is compiled based on the coverage of 40 Public Senior High School 15 Banda Aceh material questions with 3 indicators that refer to the indicator of Ennis thinking ability (1985) asking and answering questions made in the questionnaire, and determining an action to be taken, and focusing questions. Tests will be given to assess and measure the critical thinking skills of class X1 and X2 students before the experimental instrument material is used (pretest) and after the material is applied (posttest).

Critical Thinking Tests students use Likert scale questionnaire which will measure students 'critical thinking with the condition of students' curiosity, can work together with each other, caring, and honest. Criteria for positive statements and negative statements by making a total questionnaire that is as many as 20 statements. In each questionnaire, consisting of several positive statements and several negative statements, students can choose the answers according to the understanding that is felt and experienced daily, each has an alternative choice of answers that is strongly agree, agree, doubt, disagree, and strongly disagree.

\subsection{Data Analysis Technique}

a. Determine the Critical Thinking Ability Test Score and Scientific Attitude

Scores are calculated based on students' correct answers. The score obtained is then converted to a value with the following provisions: (Archambault, 2008).

$$
\text { Student Grades }=\frac{\text { Student scores }}{\text { Expected score }} \cdot x 100 \%
$$

Table 2. Index of Students' Critical Thinking Ability Categories

\begin{tabular}{|l|l|}
\hline \multicolumn{1}{|c|}{ Average Score } & \multicolumn{2}{c|}{ Category } \\
\hline $85,00-100$ & Excellent \\
\hline $80,00-84,99$ & Good \\
\hline $75,00-79,99$ & Satisfied \\
\hline $68,00-74,99$ & Bad \\
\hline $60,00-67,99$ & Unsatisfied \\
\hline
\end{tabular}

(Source: Archambault, 2008)

b. Normalized Gain Calculation (N-Gain)

Calculating the normalized Gain score using the following formula: (Sudjana, 2009)

$$
\mathrm{N}-\text { Gain }=\frac{\text { Postest Score-Pretest Score }}{\text { Maximal Score-PostestScore }} \cdot x 100 \%
$$

Information:

$$
\begin{aligned}
& \text { Height }=\text { N-Gain }>70 \\
& \text { Moderate }=30<\text { N-Gain }<70 \\
& \text { Low = N-Gain }<30
\end{aligned}
$$

The average score of normalized gain (N-Gain) obtained by each class shows the criteria for increasing students' critical thinking skills. data processing using SPSS Version 17 computer program is carried out with the following steps:

- Data entry into the SPSS Worksheet 
- Data analysis with $95 \%$ confidence level

- Data analysis is performed to test the hypotheses that have been formulated for conclusions (Unyanto, 2009)

Before the data is analyzed, the researcher tests the analysis prerequisites namely normality test, homogeneity test, hypothesis test.

\section{Discussion}

The results of research on students' critical thinking skills were obtained from the results of the pretest and posttest. The data in the table shows that students' scores before and after learning use a jigsaw cooperative model at SMA Negeri 15 Banda Aceh. Data obtained about the pretest and posttest scores of the experimental class and control class students can be displayed in the frequency distribution table below.

Table 3. Average Student Critical Thinking Pretest Value in Experiment and Control Classes

\begin{tabular}{|c|l|c|c|c|}
\hline \multicolumn{1}{|c|}{ Class } & Average & Normalitas & Homogeneity & Signifikansi \\
\hline \multirow{2}{*}{ Experiment } & 48,00 & Sig $0,378>0,05$ & & $\mathrm{t}_{\text {count }}<\mathrm{t}_{\text {table }}$ \\
& & & & $0,090<2,66$ \\
& & & \multirow{2}{*}{ Sig 0,701>0,05 } & Sig (2-tailed) \\
Control & 46,75 & Sig 0,070>0,05 & & $0,917>0,05$ \\
& & & & No different \\
& & & Real \\
\hline
\end{tabular}

(Source: Research Results, 2020)

The results of the analysis can be seen in Table 1 which shows that the average pretest score of students in the experimental class was 48.00 and the control class was 46.75 . This shows that the ability of both classes is still low in learning. To see normality, SPSS 17.0 was tested and the results were for the experimental class sig $0.378>0.05$ and for the control class Sig $0.069>0.05$. This shows that the data is normally distributed. Homogeneity test was also performed using SPSS 17.0 and the result was Sig 0.701>0.05, which means homogeneous data. Furthermore, $t$-test and the results show that $t_{\text {count }}<t_{\text {table }} 0.090<2.40$ and Sig (2-tailed) 0.927> 0.05 which shows that there is no significant difference between the experimental class pretest and the control class pretest means the initial ability that students have in the experimental class and the control class are the same. While the analysis of the students' final ability (posttest) of the experimental class and the control class can be seen in Table 4.

Table 4. Average Values of Students' Critical Thinking in Experimental and Control Classes

\begin{tabular}{|c|c|c|c|c|}
\hline Class & Average & Normalitas & Homogeneity & Signifikansi \\
\hline Experiment & 78,235 & Sig $0,052>0,05$ & \multirow{2}{*}{ Sig $0,630>0,05$} & \multirow{2}{*}{$\begin{array}{l}\mathrm{t}_{\text {count }}>\mathrm{t}_{\text {table }} \\
6,533>2,68 \\
\text { Sig }(2 \text {-tailed }) \\
0,000<0,05 \\
\text { Different } \\
\text { Real }\end{array}$} \\
\hline Control & 68,125 & Sig $0,098>0,05$ & & \\
\hline
\end{tabular}

(Source: Research Results, 2020) 
The results of the analysis in Table 4 show that the average post-test scores of students in the experimental class were 78.235 and the control class was 68.125 . To see normality, SPSS.16.0 was tested and the results were for the experimental class sig $0.052>0.05$ and for the control class Sig 0.098> 0.05. This shows that the data is normally distributed. Homogeneity testing is also carried out using SPSS. 16.0 and the result is Sig 0.630>0.05 which means homogeneous data. Furthermore, by using the Independent Samples Test it is known that the $t_{\text {count }}$ of students' critical thinking is 6.533> 2.40 and Sig (2-tailed) 0.000 $<0.05$ which indicates that there is a significant difference between the experimental class pretest and the control class pretest means the ability students have in the experimental class and the control class are different.

The increase in students' critical thinking is expressed as the difference between the pretest and posttest scores obtained by students which is usually called gain, then normalized gain (N-gain). The average value of $\mathrm{N}$-gain and critical thinking of students in the experimental class and control class can be seen in Table 5.

Table 5. Test Results of the Average N-Gain Critical Thinking of Students in the Experiment Class and Control Class

\begin{tabular}{|c|l|l|l|l|}
\hline \multicolumn{1}{|c|}{ Class } & Average & \multicolumn{1}{c|}{ Normalitas } & Homogeneity & \multicolumn{1}{c|}{ Signifikansi } \\
\hline Experiment & 68,75 & Sig 0,157>0,05 & & $\begin{array}{l}\mathrm{t}_{\text {count }}>\mathrm{t}_{\text {table }} \\
2,965>2,68 \\
\text { Sig (2-tailed) } \\
0,000<0,05 \\
\text { Different } \\
\text { Real }\end{array}$ \\
\hline Control & 61,25 & Sig 0,259>0,05 & Sig 0,072>0,05 & \\
& & & & \\
\hline
\end{tabular}

(Source: Research Results, 2020)

Based on Table 3 the results of the average N-Gain difference test and the Significance Test analyzed by $t$-test, it can be seen that $t_{\text {count }}>t_{\text {table }}(2.965>2.68)$. These results indicate that the data is significant. The difference between the N-Gain scores between the experimental class and the control class is shown in Figure 2.

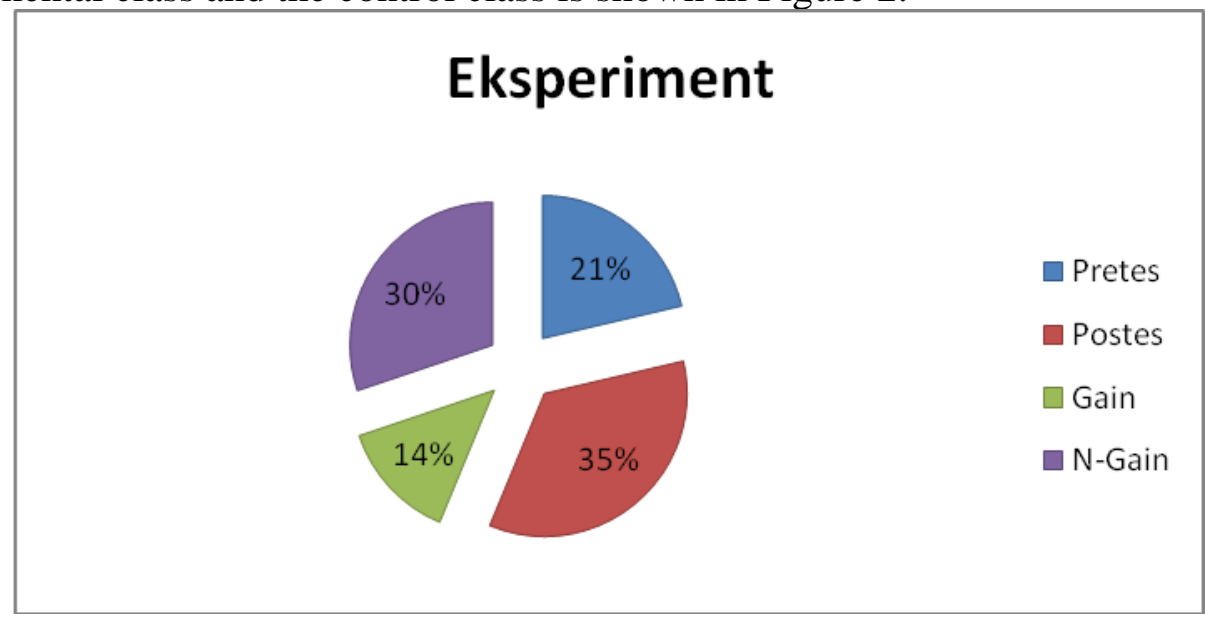

Figure 1. Difference in N-Gain Critical Thinking Scores between Students in the Experimental and Control Classes.

The results of hypothesis testing indicate that there are differences in students' critical thinking taught by applying the Jigsaw cooperative model to those taught conventionally. This is also needed by the results of the $t$ test which showed a significant difference in the 
average critical thinking of the two classes at a 95\% confidence level with $t_{\text {count }}>t_{\text {table }} 6.533>$ 2.40 and Sig (2-tailed) $0,000<0.05$ so that the obtained data significantly different, or can be used as an explanation that the type of jigsaw cooperative learning model has a higher critical thinking value than conventional learning. According to the study, Wijiastuti (2012) observations of the management of the learning activities process can improve with learning using the jigsaw learning model. So it takes an innovation given by the teacher to students that can make students memorable in learning.

The results showed that the students' ability in answering questions before learning using the jigsaw learning model was still in the low category or the initial research proved that most students were not able to answer the questions well, so the researchers took the next action, namely learning by using a jigsaw type cooperative learning model, the results of information obtained from learning conducted before the implementation of the study, while the information from the control class is low category consisting of 3 students, while the medium category is 9 students, and while the high category there are 7 students while the information in the experimental class is low category consists of 1 student, 11 students and a high category of 8 students, which can be concluded that there are differences in students' critical thinking outcomes with the use of a jigsaw type cooperative learning model.

The assessment system is carried out on groups and each group will receive an award, if the group can demonstrate the required performance. In this cooperative learning model there are several things that must be considered, namely; elements of a jigsaw cooperative learning model, jigsaw type cooperative learning principles, characteristics of a jigsaw cooperative learning model, and steps in implementing a jigsaw cooperative learning model.

\section{Conlcusion}

It can be concluded that the students' ability in answering questions before learning using the jigsaw learning model was still in the low category or the initial research proved that most students were not able to answer the questions well, so the researchers took the next action, namely learning by using a jigsaw type cooperative learning model, the results of information obtained from learning conducted before the implementation of the study, while the information from the control class is low category consisting of 3 students, while the medium category is 9 students, and while the high category there are 7 students while the information in the experimental class is low category consists of 1 student, 11 students and a high category of 8 students, which can be concluded that there are differences in students' critical thinking outcomes with the use of a jigsaw type cooperative learning model.

\section{References}

Abdullah, A. (2018). Pendekatan Dan Model Pembelajaran Yang Mengaktifkan Siswa. Edureligia; Jurnal Pendidikan Agama Islam. https://doi.org/10.33650/edureligia.v1i2.45

Almukarram, S. Ali, M., Apriana, E. (2016). Penerapan Model Pembelajaran Kooperatif Tipe Jigsaw Terhadap Peningkatan Kemampuan Berpikir Kritis Pada Konsep Pencemaran Lingkungan Di SMA Negeri 12 Banda Aceh. Jurnal Biotik, 4(1), 8-14.

Arifin, Z. D. (2013). Evaluasi Pembelajaran (Prinsip, Teknik, Prosedur). Evaluasi Pembelajaran (Prinsip, Teknik, Prosedur).

Aziz, N. (2015). Kemahiran Berfikir Kritis Pelajar Matematik Tambahan Sekolah Menengah 
(Critical Thinking Skills of Additional Mathematics Secondary School Students). Jurnal Pendidikan Matematik.

Cahyono, B. (2016). Korelasi Pemecahan Masalah dan Indikator Berfikir Kritis. Phenomenon : Jurnal Pendidikan MIPA. https://doi.org/10.21580/phen.2015.5.1.87

Charlier, N., Van Der Stock, L., \& Iserbyt, P. (2016). Peer-assisted Learning in Cardiopulmonary Resuscitation: The Jigsaw Model. Journal of Emergency Medicine. https://doi.org/10.1016/j.jemermed.2015.04.002

Davidson, N., \& Major, C. H. (2014). Boundary Crossings: Cooperative Learning, Collaborative Learning, and Problem-Based Learning. Journal on Excellence in College Teaching.

Ernawati, E., Puspita, L., \& Sari, N. P. (2016). Perbedaan Hasil Belajar Menggunakan Model Pembelajaran Hands On Activity Dengan Model Kooperatif Tipe Jigsaw Pada Pokok Bahasan Fotosintesis Kelas VII SMP Negeri 12 Batam. SIMBIOSA. https://doi.org/10.33373/sim-bio.v5i1.805

Fabri, M., Andrews, P. C. S., \& Pukki, H. K. (2016). Using design thinking to engage autistic students in participatory design of an online toolkit to help with transition into higher education. Journal of Assistive Technologies. https://doi.org/10.1108/JAT-02-20160008

Gillies, R. M. (2016). Cooperative learning: Review of research and practice. Australian Journal of Teacher Education. https://doi.org/10.14221/ajte.2016v41n3.3

Hamiyah dan Jauhar. (2014). Strategi Belajar Mengajar Di Kelas. Strategi Belajar Mengajar Di Kelas.

Hanafy, M. S. (2014). Konsep Belajar Dan PembelajaraN. Lentera Pendidikan : Jurnal Ilmu Tarbiyah Dan Keguruan. https://doi.org/10.24252/lp.2014v17n1a5

Happy, N., \& Widjajanti, D. B. (2014). Keefektifan Pbl Ditinjau Dari Kemampuan Berpikir Kritis Dan Kreatif Matematis, Serta Self-Esteem SiswA SMP. Jurnal Riset Pendidikan Matematika. https://doi.org/10.21831/jrpm.v1i1.2663

Havrylov, S., Kruszewski, G., \& Joulin, A. (2019). Cooperative Learning of Disjoint Syntax and Semantics. https://doi.org/10.18653/v1/n19-1115

Huda, M. (2013). Cooperatif Learning. pustaka pelajar.

I.W, M. V., \& Linayaningsih, F. (2017). Efektivitas Pelatihan Berfikir Positif Sebagai Strategi Coping Stress Pada Guru Sekolah Dasar Anak Berkesulitan Belajar. Jurnal Dinamika Sosial Budaya. https://doi.org/10.26623/jdsb.v18i2.574

Ismail, I. (2020). The Role of Dayah Darul Mutaalimat Grong-Grong, Pidie District in Developing Santri. Budapest International Research and Critics in Linguistics and Education (BirLE) Journal. https://doi.org/10.33258/birle.v3i1.771

Istiara, F., \& Lustyantie, N. (2017). The Influence of Cooperatif Learning Model and Critical Thinking on Essay Writing Skills (Experiment Study). World Journal of English Language. https://doi.org/10.5430/wjel.v7n2p22

Kowiyah. (2012). Kemampuan Berpikir Kritis. Jurnal Pendidikan Dasar.

Lin, H. E., McDonough, E. F., Lin, S. J., \& Lin, C. Y. Y. (2013). Managing the exploitation/exploration paradox: The role of a learning capability and innovation ambidexterity. Journal of Product Innovation Management. https://doi.org/10.1111/j.1540-5885.2012.00998.x

Mardiyanti, I. (2018). Pengaruh Model Cooperatif Learning Tipe Jigsaw Terhadap Hasil Belajar Mata Kuliah Penanganan Kegawatdaruratan Pada Mahasiswa Semester V. Journal of Health Sciences. https://doi.org/10.33086/jhs.v9i1.186

mujib. (2016). Mengembangkan Kemampuan Berfikir Kritis Melalui Metode Pembelajaran Improve. Journal of Chemical Information and Modeling. 
https://doi.org/10.1017/CBO9781107415324.004

Nasution, wahyudin nur D. (2019). strategi pembelajaran. Journal of Chemical Information and Modeling. https://doi.org/10.1017/CBO9781107415324.004

NursafraMohdZhaffar, M., \& Razak. (2017). Elemen Pemikiran Kritis Dalam Konteks Kemahiran Berfikir Aras Tinggi. ASEAN Comparative Education Research Journal on Islam and Civilization (ACER-J).

Padmowihardjo, S. (2014). Psikologi Belajar Mengajar. Pengertian Psikologi Belajar Mengajar Dan Definisi Proses Belajar.

Rachmadtullah, R. (2015). Kemampuan Berpikir Kritis Dan Konsep Diri Dengan Hasil Belajar Pendidikan Kewarganegaraan Siswa Kelas V Sekolah Dasar. Jurnal Pendidikan Dasar. https://doi.org/10.21009/jpd.062.10

Sanaie, N., Vasli, P., Sedighi, L., \& Sadeghi, B. (2019). Comparing the effect of lecture and Jigsaw teaching strategies on the nursing students' self-regulated learning and academic motivation: A quasi-experimental study. Nurse Education Today. https://doi.org/10.1016/j.nedt.2019.05.022

Shaffer, G. L., \& Shaffer, G. L. (2020). Critical Thinking: An Introduction. In Emotional Intelligence and Critical Thinking for Library Leaders. https://doi.org/10.1108/978-178973-869-820201007

Shamim, T. (2017). Critical-thinking skills. Journal of the American Dental Association. https://doi.org/10.1016/j.adaj.2016.11.006

Slavin, R. E. (2015). Instruction Based on Cooperative Learning. In Handbook of Research on Learning and Instruction. https://doi.org/10.4324/9780203839089.ch17

Sudjana, N. (2009). Penilaian Hasil Proses Belajar Mengajar. Sinarbaru.

Suprihatin, S. (2015). Upaya Guru Dalam Meningkatkan Motivasi Belajar Siswa. Promosi (Jurnal Pendidikan Ekonomi). https://doi.org/10.24127/ja.v3i1.144

Sutrisno, V. L. P., \& Siswanto, B. T. (2016). FAKTOR-FAKTOR YANG Mempengaruhi Hasil Belajar Siswa Pada Pembelajaran Praktik Kelistrikan Otomotif Smk Di Kota Yogyakarta. Jurnal Pendidikan Vokasi. https://doi.org/10.21831/jpv.v6i1.8118

Tarvainen, A., \& Valpola, H. (2017). Mean teachers are better role models: Weight-averaged consistency targets improve semi-supervised deep learning results. In Advances in Neural Information Processing Systems.

Vangrieken, K., Dochy, F., Raes, E., \& Kyndt, E. (2015). Teacher collaboration: A systematic review. Educational Research Review. https://doi.org/10.1016/j.edurev.2015.04.002

Verika, T. (2015). Perencanaan Pembelajaran. Ilmu Tarbiyah "At-Tajdid.

Wildan, W. (2017). Pelaksanaan Penilaian Autentik Aspek Pengetahuan, Sikap Dan Keterampilan Di Sekolah Atau Madrasah. Jurnal Tatsqif. https://doi.org/10.20414/jtq.v15i2.3 